\title{
Oskälig levnadsnivå? \\ En studie av inkomstnivåer \\ bland ensamstående mödrar \\ med socialbidrag
}

HUGO STRANZ \& STEFAN WIKLUND

\begin{abstract}
I artikeln behandlas $i$ vilken utsträckning inkomster bland ensamstående mödrar med socialbidrag når upp till en standardiserad normnivå, samt vilken betydelse klienternas bostadsort och individuella förutsättningar fyller för normuppfyllelse. Materialet består av ett slumpmässigt urval om 875 individer som uppbar socialbidrag någon gång under 2007 i Stockholm, Göteborg eller Malmö.
\end{abstract}

\section{Inledning}

Socialbidraget ${ }^{1}$ syftar till att garantera en ekonomisk miniminivå när enskilda

1 Sedan ett antal år tillbaka har begreppet socialbidrag formellt ersatts av ekonomiskt bistånd. Inom den vetenskapliga forskningen, och så även i den föreliggande artikeln, har dock socialbidrag kommit att kvarstå som det mest frekvent använda begreppet.

Hugo Stranz, fil dr i socialt arbete, Institutionen för socialt arbete vid Stockholms universitet.

Stefan Wiklund, docent i socialt arbete, Institutionen för socialt arbete vid Stockholms universitet. individer helt eller delvis saknar möjligheter att försörja sig på annat sätt. Bidraget handläggs med stöd av socialtjänstlagen (SoL), där varken villkoren för att erhålla ersättning eller ersättningens nivåer regleras i detalj. I lagtexten anges istället mer övergripande rättigheter och mål, däribland att bidraget ska tillförsäkra en skälig levnadsnivå (se t.ex. Regeringens prop. 1996/97:124; Regeringens prop. 2000/01:80; Socialstyrelsen, 2007, 2012). Den skäliga levnadsnivån har emellertid aldrig definierats med precision. Lagstiftarens kriterier har snarare varit knapphändiga och diffusa, där det bl. a. framgått att 
bedömningarna av den skäliga levnadsnivån ska utgå från vad som kan beskrivas som den aktuella tidpunkten och med utgångspunkt i den lokala kontexten (Regeringens prop. 2000/01:80, sid. 90ff.; jämför även Regeringens prop. 1979/80:1; Regeringens prop. 1996/97:124).

En stor del av uppgiften att definiera den skäliga levnadsnivån faller således på enskilda kommuner och handläggare. Bedömningarna ska göras individuellt, vilket dels skapar grogrund för utformning av lokalt anpassade socialbidragsnormer; dels för bedömningsvariationer mellan och inom kommuner (Stranz, 2007; Svensson, 2000). Tidigare forskning pekar bl. a. på att faktorer bland såväl socialarbetare i form av yrkeserfarenhet och syn på klienter, som på klientnivå - exempelvis kön, etnicitet och förekomst av psykosocial problematik - påverkar handläggares benägenhet att bevilja både socialbidrag och andra typer av insatser (se t.ex. Hydén et al., 1995; Kullberg, 2005, 2006; Stranz, 2007; Wallander \& Blomqvist, 2008). Sådana faktorer kan därmed väntas vara av betydelse såväl för fastställandet av vad som är att betrakta som en skälig levnadsnivå, som för möjligheterna att nå densamma.

Sedan 1990-talets början har socialbidragets praktiska funktion till viss del förändrats. För det första är socialbidraget $\mathrm{i}$ dagsläget av betydelse för allt fler hushåll. Detta behov har därtill - för det andra över tid kommit att bli allt mer varaktigt (Bergmark \& Bäckman, 2007; Socialstyrelsen, 2010, 2011). Möjligen kan de förlängda bidragstiderna påverka bedömningen av den skäliga levnadsnivån - ju längre tid av ekonomisk utsatthet, desto större behov av bidrag till utgifter som förekommer mer sällan. Förändringarna innebär för det tredje att människors försörjningsproblem i mindre utsträckning än tidigare betingas av individuella hinder, exempelvis psykosocial problematik. Av större betydelse är istället mer grundläggande klientegenskaper som etnicitet, kön och hushållstyp (Halleröd, 2003, Stranz \& Wiklund, 2012; jämför Hammarstedt, 2009; Mood, 2011).

I vilken utsträckning socialbidraget i någon mening tillförsäkrar en skälig levnadsnivå är inte klarlagt. Detta beror naturligtvis på själva begreppets oklarhet (jämför Hjort, 2010; Socialstyrelsen, 2007), men också på att försök till operationaliseringar av skälig levnadsnivå sällan gjorts inom forskningen. I föreliggande studie relateras den skäliga levnadsnivån till en standardiserad socialbidragsnorm, som beräknats med utgångspunkt i socialbidragets försörjningsstödsdel. ${ }^{2}$ Oavsett hur operationaliseringen görs, är det dock tänkbart att andelen bidragstagare som uppnår en skälig levnadsnivå varierar mellan olika klientgrupper och regioner. En av de kanske mest angelägna klientgrupper att studera i detta avseende är ensamstående mödrar ${ }^{3}$. Denna grupp är sedan lång tid tillbaka kraftigt överrepresenterad bland bidragshushåll med såväl kortvariga behov som bland lång-

2 Beräkningarna av den standardiserade normen, samt vad denna innefattar, presenteras i artikelns metodavsnitt.

3 Med ensamstående mödrar respektive ensam stående kvinnor med barn avses fortsättningsvis ej sammanboende kvinnor med hemmavarande barn under 18 år $i$ hushållet.

Hugo Stranz \& Stefan Wiklund: Oskälig levnadsnivå? En studie av inkomstnivåer... 
variga socialbidragstagare ${ }^{4}$ (se t.ex. Fritzell et al., 2007; Socialstyrelsen, 2010, 2011; Stranz \& Wiklund, 2011, 2012) och deras ekonomiska situation har även konsekvenser för ett betydande antal barn.

Under 2010 levde runt 8 procent av alla barn i Sverige i ett hushåll som mottog socialbidrag. Närmare 50 procent av dessa barn levde med en ensamstående förälder, som i merparten av fallen var en ensamstående mamma (Socialstyrelsen, 2011; jämför även Salonen, 2012). Känt är att det finns överrisker för olika slags negativa utfall på sikt (t.ex. psykiska sjukdomar och självmordsförsök) bland barn vars föräldrar uppbär socialbidrag, samt att riskerna ökar i takt med bidragstagandets varaktighet (Socialstyrelsen, 2006). Det är också klarlagt att det finns ett samband mellan att växa upp i ett hushåll med socialbidrag och att själv senare i livet vara i behov av bidrag. Sambandet är dock komplext och går via förekomsten av andra individuella problem (Stenberg, 2000). Med hänsyn till det barnperspektiv som i SoL anges som en överordnad princip för socialtjänstens arbete, är det tänkbart att incitamenten för att säkerställa en viss ekonomisk standard är som störst i relation till familjer med barn. Detta skulle i så fall kunna få konsekvenser för socialbidragsbedömningarna som görs visavi ensamstående mödrar.

I den föreliggande artikeln behandlas

4 Långvarigt socialbidragstagande kan mätas på flera olika sätt (se t.ex. Dahl \& Lorentzen, 2003). I den föreliggande artikeln avses genomgående s.k. nettovaraktighet; bidragstagande $\geq 10$ månader under ett kalenderår, vilket är koherent med den offentliga statistikföringen på området (jämför Socialstyrelsen, 2011). data från projektet "Ensamstående mödrar - välfärd, försörjning och socialtjänst". Projektet innefattar ett slumpmässigt urval av klienter i den aktuella gruppen som uppbar socialbidrag någon gång under 2007 i någon av storstäderna Stockholm, Göteborg eller Malmö. Syftet med artikeln är att beskriva i vilken utsträckning klientgruppens inkomster når upp till nivån på en schablonberäknad och standardiserad socialbidragsnorm. Artikeln syftar vidare till att analysera vilka faktorer som kan vara av betydelse för om inkomsterna når upp till denna nivå. Följande frågeställningar beaktas:

1. I vilken utsträckning motsvarar ensamstående mödrars sammantagna inkomster nivån på en standardiserad socialbidragsnorm under 2007 ?

2. Föreligger det variationer mellan landets tre storstäder vad gäller ensamstående mödrars möjligheter att nå upp till en sådan norm?

3. Vilken betydelse kan bakgrundsfaktorer (t.ex. etnicitet och utbildningsnivå), faktorer som avser relationen till arbetsmarknaden (t.ex. förekomst av löneinkomster och ersättning från socialförsäkringen) samt individuell hälsoproblematik (t.ex. psykisk ohälsa och psykosocial problematik) ha för klientgruppens möjligheter att nå denna norm?

\section{Bakgrund}

\section{Socialbidraget och socialbi- dragsnormen}

Att socialbidraget ska tillförsäkra en 
skälig levnadsnivå ${ }^{5}$ har varit gällande ända sedan SoL ursprungligen trädde ikraft vid 1980-talets början. Frågan om vad begreppet egentligen står för har behandlats såväl i de förarbeten som föregick den ursprungliga lagstiftningen (se t.ex. Regeringens prop. 1979/80:1), som i förarbetena till senare års revideringar (Regeringens prop. 1996/97:124; Regeringens prop. 2000/01:80; se även Stranz, 2007; Svensson, 2000). Något mer precist svar på frågan har dock aldrig lämnats. Hänvisningar till att den skäliga levnadsnivån ska bedömas med utgångspunkt $\mathrm{i}$ exempelvis den lokala kontexten (se t.ex. Regeringens prop. 2000/01:80) - som i sin tur föranleder att t.ex. nivån på acceptabla boendekostnader ska jämställas med vad en låginkomsttagare på orten kan väntas kunna kosta på sig (se t.ex. Regeringens prop. 1996/97:124, sid. 83) - innebär emellertid att ett definitionsproblem hanterats med hjälp av ett annat.

Sedan 1998 regleras dock delar av socialbidraget via den s.k. riksnormen (Regeringens prop. 1996/97:124), som är en schablonberäknad och för landet enhetlig miniminivå med avseende på ett givet antal poster (t.ex. livsmedel, hygien och TV-licens). Tillsammans med ytterligare ett antal ej schablonberäknade kostnader (t.ex. hyra, elkostnader och fackavgift) motsvarar riksnormen det s.k. försörjningsstödet $^{6}$, som är en av socialbidragets två delar. De utgiftsposter som inte innefat-

5 Anges i dagens lagstiftning i kap. 4, 1§.

6 En fullständig beskrivning av vilka poster, samt nivåerna på dessa, som inkluderas i försörjningsstödet ges i metodavsnittet. tas i försörjningsstödet utgör socialbidragets andra del, det s.k. övriga ekonomiska biståndet.

När SoL trädde ikraft under 1980-talets inledning, var socialbidragshandläggningen en relativt oreglerad arena. Först 1985, i samband med att Socialstyrelsens allmänna råd presenterades för första gången, tillhandahölls en socialbidragsnorm. Jämfört med riksnormen var Socialstyrelsens ursprungliga norm inte bara mer heltäckande i termer av de utgiftsposter den omfattade; de schablonberäknade beloppen var också mer generösa. Socialstyrelsens norm fungerade dock bara vägledande. En stor del av förutsättningarna för socialbidragshandläggningen hämtades därmed från de beslut som fattades vid förvaltningsdomstolarna i samband med att enskilda bidragsbeslut överklagades. 1994 möjliggjorde en dom i Regeringsrätten användandet av den s.k. Tingsrydsnormen, som innebar att ett antal av de poster som Socialstyrelsens norm innefattade uteslöts ur det schabloniserade totalbeloppet (Johansson, 2001). Ett par år senare justerades Socialstyrelsens norm mot Tingsrydsnormen (Socialstyrelsen, 2000), som också stämmer överens med dagens riksnorm (jämför Regeringens prop. 1996/97:124; Regeringens prop. 2000/01:80).

Till skillnad från vad som kan väntas ha varit ambitionen med riksnormen, exempelvis att öka graden av förutsebarhet i beslutsfattandet och möjliggöra planering av den egna ekonomin, pekar därtill flera studier på att villkoren på klientnivå försämrades i samband med dess införande. Utöver tidigare påpekade bedömningsvariationer, medförde riksnormen bl. a. också

Hugo Stranz \& Stefan Wiklund: Oskälig levnadsnivå? En studie av inkomstnivåer... 
en generell nedjustering av socialbidragsnivåerna (Hjort, 2010; Socialstyrelsen, 2000).

Riksnormens reella funktion för att svara mot vad som kan väntas innefattas i en skälig levnadsnivå kan betraktas som relativt marginell; dels täcker normen bara en viss del av en av socialbidragets två delar - försörjningsstödet - dels är den uppenbart restriktiv jämfört med de normnivåer som Socialstyrelsen förespråkade en bit in på 1990-talet. På enskild månadsbasis kan försörjningsstödet i dess helhet - alltså riksnormen plus individuellt bedömda medel för exempelvis boende - möjligen fungera som en absolut miniminivå. Med tanke på de generellt sett förlängda bidragstider som gäller för dagens bidragstagarpopulation (Socialstyrelsen, 2010, 2011), är det dock rimligt att vänta sig att behovet av övrigt ekonomiskt bistånd ökat. Inte heller här förekommer några enhetliga nivåer av den karaktär som utmärker riksnormen.

Det faktum att bara en begränsad del av socialbidraget är tydligt reglerad, har bidragit till en lokal, kompletterande regelutveckling (Stranz, 2007). Denna lokala regelutformning gäller även för socialbidragets andra del, det övriga ekonomiska biståndet, som ska täcka alla de kostnader som inte innefattas i försörjningsstödet. Det kan handla om kostnader för tand- och läkarvård, men även glasögon, sällanköpsvaror, särskilda kostnader med avseende på barn, etc. (jämför Regeringens prop. 1996/97:124; Regeringens prop. 2000/01:80; Svensson, 2000). Även om de lokala reglerna ofta konstrueras med stöd av Socialstyrelsens allmänna råd, utgör de inte någon garanti för enhetliga nivåer över riket (Hjort, 2010; Stranz, 2007).

\section{Socialbidrags- handläggningen}

Socialtjänstens arbete är av tradition individ- och familjeorienterat. Det innebär bl. a. att faktorer med uppenbar strukturell koppling - t.ex. arbetslöshet - hanteras med hjälp av individuellt riktade insatser och program (Johansson, 2001). Denna trend, där exempelvis arbetslöshet möts med olika typer av aktiveringsprogram, har dessutom förstärks under det senaste decenniet (se t.ex. Nybom, 2011).

Socialbidragshandläggare, som liksom övriga socialarbetare ofta brukar definieras som gräsrotsbyråkrater, har till sin huvudsakliga uppgift att tillämpa olika typer av formella regler i relation till enskilda klienter (se t.ex. Lipsky, 1980). Då socialtjänstens primära regelverk, SoL, i första hand fastställer mål och i mindre utsträckning hur dessa ska uppnås, har socialarbetare även tillgång till betydande diskretion i yrkesutövandet (Evans \& Harris, 2004; Hasenfeld, 1983). Även om socialarbetare delvis agerar kollektivt, innebär det individuella tolkningsutrymmet att varje enskilt möte mellan en handläggare och en klient präglas av situationsunik interaktion. I samband med denna interaktion ska socialarbetaren bl. a. förmedla relevant information om regelverkens uppbyggnad, rutiner och eventuella krav. Informationsförmedlingen, som till stor del är grunden för klientens möjligheter att erhålla socialbidrag, baseras därtill i stor utsträckning på handläggarens person- 
liga värderingar (Hydén, 1996; Lipsky, 1980; Stranz, 2007). Den lokala regelutveckling som förekommer på socialbidragsområdet syftar delvis till att begränsa den individuella handlingsfriheten (Stranz, 2007; jämför även Brunsson \& Jacobsson, 1998).

Jämfört med andra socialarbetargrupper är socialbidragshandläggare den yrkeskategori som uppvisar den lägsta graden av professionsutveckling (Dellgran \& Höjer, 2003). En bidragande orsak till det kan vara att regelutvecklingen, och därmed den formella begränsningen av den individuella handlingsfriheten, är särskilt stark på socialbidragsområdet. Diskretion vid utförandet av arbetsuppgifter fyller en central funktion både för förstärkningen av den egna professionella statusen och för ambitionen att utföra sitt arbete i enlighet med organisationens mål (Lipsky, 1980; May \& Winter, 2009).

Tidigare forskning visar inte bara på betydande variationer i socialbidragsbedömningarna; mycket tyder också på att skillnaderna tilltagit $\mathrm{i}$ takt med att antalet regler ökat (Stranz, 2007). Ytterligare regler innebär utökade tolkningsmöjligheter - socialarbetarna förväntas inte bara tillämpa en målformulerad lagstiftning, utan även mer eller mindre konkreta lokala direktiv i relation till enskilda klienter (Evans \& Harris, 2004). Även i bedömningsarbetet fyller socialarbetarnas personliga värderingar en betydande roll. Handläggare som önskar ökade möjligheter att kontrollera klienterna är mer restriktiva än andra, medan det motsatta gäller för handläggare som anser att socialbidraget generellt sett underutnyttjas (se t.ex. Hydén et al., 1995; Hydén, 1996; Stranz, 2007; Terum, 2002).
Betydelsen av personliga värderingar kan också få genomslag med avseende på faktorer som knyter an till kön och föräldraskap - ensamstående fäder tenderar inte bara att bedömas hårdare än ensamstående mödrar, utan mottar även mer arbetsmarknadsrelaterat stöd (Kullberg, 2005, 2006).

\section{Klienternai socialbidragssystemet}

Då socialbidragstagandets orsaker diskuteras görs ofta en åtskillnad mellan faktorer av strukturell respektive individuell karaktär (se t.ex. Halleröd, 2003; Stranz \& Wiklund, 2011). Distinktionen mellan vilka faktorer som ska hänföras till den ena respektive andra kategorin är dock inte självklar - för den enskilda individen är arbetslöshet i hög grad ett individuellt problem, medan det på en aggregerad nivå främst är att se som ett strukturellt sådant. Det kan därmed finnas skäl att låta kategoriseringen ta sin utgångspunkt $\mathrm{i}$ vilken typ av empiri som ligger för handen; på individnivå kan faktorer som traditionellt anförs som strukturella - t.ex. etnicitet och kön - betraktas som grundläggande klientegenskaper, medan aspekter som tar sikte på mer föränderliga förhållanden som avser ohälsa, utbildningsnivåer, etc. kan definieras som klientförhällanden. Denna distinktion är också utgångspunkten för kommande analyser - som baseras

7 För ytterligare diskussion kring hur relationen mellan strukturella och individuella faktorer kan förstås, se t.ex. Stranz \& Wiklund, 2011 alt. Halleröd, 2003.

Hugo Stranz \& Stefan Wiklund: Oskälig levnadsnivå? En studie av inkomstnivåer... 
på individdata - där vi knyter faktorer som $i$ andra sammanhang ofta hänförs till strukturell nivå (t.ex. arbetslöshet och etnicitet) till enskilda individer. Oavsett vilken nivå dessa faktorer hänförs till, är det tänkbart att de kan påverka bedömningen av den skäliga levnadsnivån (jämför Kullberg, 2005, 2006; Stranz, 2007; Wallander \& Blomqvist, 2008).

Till de mer betydelsefulla klientegenskaperna av demografisk karaktär hör att vara utrikes född eller ung. Under 2010 uppbar 8 procent av samtliga personer i spannet 18-29 år socialbidrag någon gång under året, vilket kan jämföras med omkring 6,5 procent i den totala befolkningen. Bland utrikes födda personer uppgick socialbidragstagandet till 12 procent under samma år (Socialstyrelsen, 2011). Jämfört med svenskfödda personer är invandrares bidragstagande därtill i högre grad långvarigt (Hammarstedt, 2009; Mood, 2011).

Bidragstagandets utbredning bland ungdomar och utrikes födda personer är dock väsentligt lägre än de närmare 25 procent som gäller för ensamstående mödrar (Socialstyrelsen, 2011). De ensamstående mödrarnas framträdande position bland bidragshushållen har till stor del kopplats till betingelser som många gånger gäller även för kvinnor generellt. Jämfört med män uppvisar kvinnor i allmänhet en lägre grad av förvärvsarbetsfrekvens, en högre sysselsättningsgrad i sektorer med ett relativt sett lägre löneläge, lägre ersättningsnivåer från socialförsäkringen, etc. (se t.ex. Nermo, 2004; Socialstyrelsen, 2010; Yazdanpanah, 2008).

Bland ensamstående kvinnor med barn blir denna form av könssegregerande mönster extra problematiska, då exempelvis möjligheter till stordriftsfördelar som märks bland sammanboende saknas (Gähler, 2001). Mycket tyder därtill på att ensamstående mödrar i lägre grad än bidragstagarkollektivet generellt berörs av vissa typer av problematiska individuella förhållanden, t.ex. psykosociala hinder som missbruk, medan förekomsten av psykisk och somatisk problematik ligger på ungefär samma nivå som för övriga (Nybom et al., 2005; Socialstyrelsen, 2010; Stranz, 2002; Stranz \& Wiklund, 2011).

\section{Material och metod}

Artikeln baseras på ett slumpmässigt urval $(\mathrm{n}=875)^{8}$ av samtliga ensamstående kvinnor med barn som mottog socialbidrag (exklusive s.k. introduktionsersättning) någon gång under $2007 \mathrm{i}$ någon av storstäderna Stockholm, Göteborg eller Malmö. Urvalet speglar omkring 10 procent av den totala populationen ( $\mathrm{N}=8$ 434). ${ }^{9}$ Klienterna är proportionerligt spridda med avseende på antal bidragshushåll av den aktuella typen i respektive stad och stadsdel (Stockholm, 14 stadsdelar; Göteborg, 19 stadsdelar; Malmö, 10 stadsdelar). ${ }^{10}$

8 Det ursprungliga samplet omfattar 895 ärenden -20 ärenden (ca. 2 procent) utgör externt bortfall.

9 Stockholm ( $\mathrm{N}=3$ 293), Göteborg ( $\mathrm{N}=3$ 323), Malmö (N=1 818).

10 Vid tidpunkten för datainsamling bestod Göteborg av 21 stadsdelar. 2 av dessa stadsdelar hade alltför få (8 respektive 11) ärenden av den aktuella typen för att komma att ingå $\mathrm{i}$ urvalet. 
Det är också till landets tre storstäder som resultaten formellt sett kan generaliseras. Resultaten kan dock väntas ha viss giltighet även i förhållande till storstädernas kranskommuner. På samma sätt som materialet brister med avseende på riksrepresentativitet, i huvudsak till följd av att de strukturella förutsättningarna i storstadsområden i hög grad avviker från vad som gäller för övriga riket, talar en sådan strukturell profil för viss jämförbarhet med närbelägna kommuner.

Materialet inhämtades via enkäter riktade till de socialarbetare $(n=451)$ som ansvarade för handläggningen av respektive ärende. Detta har möjliggjort att inhämta klientuppgifter som inte går att nå via registerstudier. Datainsamlingen föregicks av ett omfattande implementeringsarbete, som bl. a. innebar att samtliga berörda arbetsgrupper besöktes av en projektmedarbetare. Vid de arbetsplatsförlagda besöken - totalt 38 stycken - presenterades och distribuerades den enkät som låg till grund för inhämtande av data.

Formulären täcker av detaljerade klientuppgifter i form av bakgrundsdata, koppling till arbetsmarknaden, socialbidragstagande/försörjning, hälsofaktorer, handläggningsrutiner/insatser och förhållanden som avser barnen i familjen (för fördjupad information om studiens praktiska upplägg och detaljer kring inhämtade uppgifter, se Stranz \& Wiklund, 2011). I enlighet med studiens tvärsnittskaraktär, är varje enskild fråga besvarad med utgångspunkt i de förhållanden som gällde i samband med den senaste socialbidragsutbetalningen 2007.

Genom att inhämta uppgifter direkt från ansvariga socialarbetare speglar mate- rialet inte bara förhållanden som inte framgår av socialtjänstens register - renodlade registeruppgifter (t.ex. utbetalade socialbidragssummor och aktuella månader med socialbidrag) har dessutom kunnat valideras av socialarbetarna. Matchningen av ansvariga handläggare i relation till enskilda klienter har i sin tur, tillsammans med det övriga implementeringsarbetet, sannolikt varit en bidragande faktor till höga svarsfrekvenser. Uppgifter som avser olika inkomstposter utgör undantaget från ett i övrigt genomgående lågt internbortfall (frågor om födelseland och antal arbetstimmar/vecka uppvisar ett internbortfall om ca fyra respektive åtta procent, i övrigt noteras enbart enstaka bortfall). Vad gäller inkomstposterna är omkring 15 procent $(n=150)$ av fallen att beteckna som ofullständiga - handläggarna har registrerat avsaknad/förekomst av en viss typ av ersättning, men inte redovisat nivån på den utbetalade summan.

Ytterligare en aspekt som får återverkningar på validiteten i materialet, är att vi saknar kontroll för om klienten bytt handläggare mellan tidpunkten för den senaste socialbidragsutbetalningen och enkätens ifyllande (gäller för uppskattningsvis 10-20 procent av klienterna). I samband med arbetsplatsbesöken instruerades enhetscheferna att ta ett samordnande ansvar för ifyllnaden av dessa formulär. Materialet speglar också bedömningar/uppfattningar bland socialarbetare. Det kan inte uteslutas att deras uppfattningar kring vissa uppgifter avviker från klienternas.

Analyser och tolkning av tvärsnittsdata är inte helt oproblematiskt. Jämfört med longitudinella designer tenderar sådana

Hugo Stranz \& Stefan Wiklund: Oskälig levnadsnivå? En studie av inkomstnivåer... 
data bl. a. att fånga högre andelar av särskilt marginaliserade individer (Bergmark \& Bäckman, 2004), liksom att retrospektiva studier av långvarigt bidragstagande, som fokuserar s.k. nettovaraktighet, kan medföra fler berörda hushåll jämfört med andra varaktighetsmått (Dahl \& Lorentzen, 2003). I den kommande resultatredovisningen analyseras ensamstående mödrars inkomster i relation till en standardiserad normnivå, som är avsedd att spegla socialbidragets försörjningsstödsdel. Datas karaktär medför att vi enbart har kontroll över inkomster och bidrag under den månad under 2007 då klienten senast mottog socialbidrag. Vi saknar därmed uppgifter om sparade medel (t.ex. från lön/bidrag under tidigare månader), som i sin tur kan påverka socialbidragsnivån under den aktuella månaden negativt. Sammantaget finns därmed en risk att de inkomstnivåer som redovisas är lågt skattade.

\section{En standardiserad socialbidragsnorm}

Vi har konstruerat en standardiserad socialbidragsnorm mot basis av socialbidragets försörjningsstödsdel. Det innebär att vi utgått från samma kriterier som vid en reguljär bidragsbedömning. Den standardiserade socialbidragsnormen kan därmed ses som en absolut miniminivå. Beräkningen har gjorts per hushåll och avser schabloniserade månadskostnader.

För ett ensamhushåll utgörs försörjningsstödet/den standardiserade normen av 1) riksnormen för 2007, som inkluderar personliga kostnader (livsmedel, kläder/ skor, fritid/lek, hygien och - för barn barn-/ungdomsförsäkring) samt gemensamma hushållskostnader (förbrukningsvaror, dagstidning, telefon och TV-licens). Till normen har vi även fört 2) skäliga boendekostnader. Utöver att sådana kostnader ska täckas av försörjningsstödet, har det i internationell forskning anförts som centralt för fastställandet av vad som är att betrakta som en skälig levnadsnivå (se t.ex. Borgeraas \& Dahl, 2010; Renwick \& Bergmann, 1993).

Då inhämtade data inte omfattar uppgifter om hyresnivåer på enskild klientnivå, har kostnaderna fastställts i enlighet med SCB:s genomsnittshyror för 2007 (SCB/Statistiska meddelanden BO 39 SM 0801). I huvuddelen av fallen $(n=714)$ har hyran bestämts med stöd av den bostadsstorlek som angivits. I de fall där uppgifter om bostadens storlek saknas $(n=158)$ har denna skattats mot trångboddhetsnorm 3 (antal familjemedlemmar minus 1 rum och kök). SCB:s genomsnittshyror innefattar särredovisningar för Stor-Stockholm och Stor-Göteborg, medan uppgifter för Malmö saknas. Här har nivåerna bestämts i enlighet med SCB:s uppgifter för större kommuner.

Den standardiserade normen inkluderar även 3) kostnader för hushållsel enligt Konsumentverkets (2007) schablon för storstäder 2007. Schablonen bygger på ett månatligt estimat i $\mathrm{kWh}$, vilket har omsatts i ett ungefärligt belopp i kronor med stöd av det genomsnittliga kWh-priset för 2007 (76 öre) plus skatt (26,5 öre) och moms (26 öre): 1,28 kronor/kWh. Nätavgifter är inte inkluderade i beräkningen, vilket innebär att de schabloniserade elkostnaderna är 
något lågt räknade. Till normen förs även 4) schablonkostnader för hemförsäkring $i$ storstäder, som varierar med antalet personer i hushållet. Punkterna 1-4 sammanfattas i Tabell 1.

Ytterligare två kostnadsposter inkluderas i den standardiserade normen: 5) a-kasseavgift samt 6) kostnader för arbetsresor. Då våra data inte innefattar uppgifter om vilken a-kassa klienterna tillhör, enbart uppgifter om de är anslutna eller inte, har avgiften satts med utgångspunkt $i$ ett medlemskap i Kommunalarbetarnas a-kassa. Detta är i linje med beräkningsunderlag som bl. a. använts då Socialstyrelsen (2007) granskat socialbidragsnormen. För 2007 uppgick a-kasseavgiften till 340 kronor för arbetande personer $(\mathrm{n}=142)^{11}$ och 100 kronor för arbetslösa $(n=728)$ (Kjellberg, 2010). När det gäller kostnader för arbetsresor har dessa schabloniserats i enlighet med Socialstyrelsens (2007) beräkningar, vilket innebär att de ska täcka utgifterna för ett månadskort för lokaltrafiken. Under 2007 uppgick denna kostnad till 620

11 För hel-/deltidsarbetande, där fackföreningsavgiften schabloniserats till 340 kronor, har kostnader för hemförsäkring - som kan väntas ingå $\mathrm{i}$ fackföreningsavgiften - exkluderats.

\section{Tabell I.}

Standardiserad socialbidragsnormi kronor/månad. Alla uppgifter avser 2007.

\begin{tabular}{|c|c|c|c|c|c|c|c|}
\hline \multicolumn{8}{|c|}{ Personliga kostnader (riksnorm) } \\
\hline Vuxen & $\begin{array}{l}\text { Barn } \\
<1 \text { år }\end{array}$ & $\begin{array}{l}\text { Barn } \\
\text { I-2 år }\end{array}$ & $\begin{array}{l}\text { Barn } \\
3 \text { år }\end{array}$ & $\begin{array}{l}\text { Barn } \\
4-6 \text { år }\end{array}$ & $\begin{array}{c}\text { Barn } \\
7-10 \text { år }\end{array}$ & $\begin{array}{l}\text { Barn } \\
\text { ||-14 år }\end{array}$ & $\begin{array}{l}\text { Barn } \\
15-18 \text { år }\end{array}$ \\
\hline 2640 & 1560 & 1770 & 450 & 1770 & 1980 & 2270 & 2550 \\
\hline \multicolumn{8}{|c|}{ Gemensamma kostnader (riksnorm) } \\
\hline I pers & 2 pers & 3 pers & 4 pers & & & 6 pers & 7 pers \\
\hline 830 & 930 & $1 \mid 60$ & 1340 & & & 1740 & 1910 \\
\hline \multicolumn{8}{|c|}{ Genomsnittliga månadshyror (bostadsstorlek och stad/region) } \\
\hline & \multicolumn{2}{|r|}{ I rok } & 2 rok & 3 rok & \multicolumn{2}{|c|}{4 rok } & $5+$ rok \\
\hline Stockholm & \multicolumn{2}{|r|}{3535} & 4721 & 5690 & \multicolumn{2}{|c|}{6877} & 8974 \\
\hline Göteborg & \multicolumn{2}{|r|}{3362} & 4425 & 5370 & \multicolumn{2}{|c|}{6604} & 8099 \\
\hline Malmö & \multicolumn{2}{|r|}{3142} & 4260 & 5154 & \multicolumn{2}{|c|}{6414} & 7921 \\
\hline \multicolumn{8}{|c|}{ Kostnader hushållsel } \\
\hline I pers & \multicolumn{2}{|l|}{2 pers } & 4 pers & \multicolumn{2}{|c|}{5 pers } & 6 pers & 7 pers \\
\hline 192 & 282 & 345 & \multirow{2}{*}{$\begin{array}{c}397 \\
\text { rsäkrinosk }\end{array}$} & \multicolumn{2}{|c|}{422} & 448 & 461 \\
\hline \multicolumn{7}{|c|}{ Hemförsäkringskostnader } & \\
\hline I pers & 2 pers & 3 pers & 4 pers & & ers & 6 pers & 7 pers \\
\hline 150 & 160 & 170 & 180 & & & 200 & 220 \\
\hline
\end{tabular}

Hugo Stranz \& Stefan Wiklund: Oskälig levnadsnivå? En studie av inkomstnivåer... 
kronor i Stockholm, 370 kronor i Malmö samt $457^{12}$ kronor i Göteborg. Kostnader för arbetsresor har enbart beräknats för hel-/deltidsarbetande klienter (Stockholm: n=54, Göteborg: n=60, Malmö: n=28).

I Tabell 2 ges ett konkret exempel på hur den standardiserade normen har beräknats på hushållsnivå. Här behandlas ett typhushåll i Göteborg, innefattande en ensamstående, arbetslös kvinna med två hemmavarande barn.

Standardiseringen av socialbidragsnormen kräver vissa reservationer. För det första saknar vi möjlighet att beakta sådana variationer som kan vara av betydelse för socialarbetare då de i varje enskilt fall ska avgöra vad som är att betrakta som en skälig levnadsnivå. En faktor som kan föranleda individuella variationer - och som vi saknar kontroll för - är, som påtalats, förekomsten av sparade medel; sådana ska tas

12 Medelvärdet av 515 (t.o.m. 19/8) respektive 400 kronor (fr.o.m. 20/8) är 457 kronor. med i beräkningen vid fastställandet av den skäliga levnadsnivån. För det andra bygger stora delar av klienternas boendekostnader på estimat. Det kan inte uteslutas att de faktiska kostnaderna i flera fall är lägre än de genomsnittliga hyrorna. Då socialbidraget ska spegla vad en låginkomsttagare kan antas kunna kosta på sig (Regeringens prop. 1996/97:124; Svensson, 2000) kan vi alltså i vissa fall ha överskattat normnivån. Risken för överskattning av hyresnivåerna gäller även för de fall där vi estimerat bostadsstorleken mot trångboddhetsnorm 3. Vi har i en tidigare studie (Stranz \& Wiklund, 2011) visat på en relativt hög grad av trångboddhet i undersökningsgruppen, vilket också kan gälla för de fall där vi saknar uppgifter om bostadens faktiska storlek.

För det tredje finns dock även aspekter som talar för att den standardiserade normen innebär att enskilda klienters ekonomiska behov underskattas. Normen tar enbart sikte på socialbidragets försörjningsstödsdel, samtidigt som bidrag som faller inom ramen för det övriga ekono-

\section{Tabell 2.}

Standardiserad socialbidragsnorm (2007) $i$ kronor/månad. Typhushåll.

\begin{tabular}{lc}
\hline Personliga kostnader, vuxen & 2640 \\
Personliga kostnader, barn I (3 år) & | 450 \\
Personliga kostnader, barn 2 (7 år) & 1980 \\
Gemensamma kostnader & 1160 \\
Hyra (trångboddhetsnorm 3 = 4 rok) & 6604 \\
Hushållsel & 345 \\
Hemförsäkring & 170 \\
A-kasseavgift & 100 \\
Arbetsresor & - \\
\hline Total & 14449 \\
\hline
\end{tabular}


miska biståndet många gånger kan krävas för att möta de förhållanden som gäller på individuell nivå (jämför Hjort, 2010; Regeringens prop. 2000/01:80).

\section{Analyser}

I syfte att belysa vilka faktorer som är av vikt för om ensamstående mödrars inkomster når upp till en standardiserad normnivå eller inte, använder vi logistisk regressionsanalys. Beroendevariabel i analyserna är standardiserad normuppfyllelse (norm uppfylld $=0$, norm ej uppfylld =1), som bygger på varje enskild klients a) sammantagna inkomster och motsvarande ${ }^{13}$ i samband med den senaste månaden för mottagande av socialbidrag under 2007 dividerat med b) standardiserad socialbidragsnorm enligt modellen ovan.

Två separata regressionsanalyser genomförs. I den första analyseras bostadsortens betydelse för bristande normuppfyllelse, med kontroll för såväl klientegenskaper som klientförhållanden. I den andra analyseras klientegenskapernas och klientförhållandenas betydelse för bristande normuppfyllelse för undersökningsgruppen i dess helhet (ingen hänsyn tas därmed till klien-

13 Skattepliktiga inkomster (lön, a-kassa, sjukpenning/-ersättning och föräldrapenning) + bidrag/ersättningar (barnbidrag inklusive eventuella flerbarnstillägg, underhållsstöd/-bidrag, studielån/-bidrag, bostadsbidrag, eventuella övriga bidrag) + socialbidrag. ternas bostadsort $\left.{ }^{14}\right)$. De oberoende variablerna omfattar klientegenskaper som ålder och etnicitet, medan klientförhållanden speglas utifrån variabler som knyter an till arbetsmarknadsförankring, försörjningssituation, bidragstagande och olika typer av ohälsa/hinder.

Valet av oberoende variabler bygger $i$ första hand på resultat från tidigare forskning och någon multikolleniaritet ${ }^{15}$ dem emellan föreligger inte. De oberoende variablerna har kodats enligt följande:

- Bostadsort: Stockholm (ref.); Göteborg (1); Malmö(2). ${ }^{16}$

- Etnicitet: klientens födelseland - Sverige (ref.); utanför Sverige (1).

- Ålder: ålder mätt i år (kontinuerlig variabel).

- Utbildningsnivå: högsta avslutade utbildning - $\geq$ gymnasium (ref.); < gymnasium (1). Till utbildning under gymnasienivå hänförs såväl färdigställd som ej färdigställd grundskola.

14 Under analysarbetet har vi kontrollerat för möjligheterna att genomföra separata logistiska regressionsanalyser för respektive stad. I samband med att materialet delas mellan städerna blir antalet observationer inom ramen för de oberoende variablernas respektive svarsalternativ $i$ flera fall relativt få, varför detta inte är möjligt.

15 Multikollinearitet har kontrollerats med Pearson's $r$. De enda nämnvärda interna sambanden föreligger mellan variablerna arbetslöshet och socialförsäkring (447) samt psykosociala problem och psykisk ohälsa (,389). Gränsen för multikollinearitet sätts vanligen vid interna samband $>(-), 700$ (se t.ex. Tabachnick \& Fidell, 2001).

16 Används enbart i den första regressionsanalysen.

Hugo Stranz \& Stefan Wiklund: Oskälig levnadsnivå? En studie av inkomstnivåer... 
- Arbetslöshet: $i$ arbete (ref); arbetslös (1). Som arbetslösa betraktas även klienter som är SFI-studerande.

- Socialförsäkringsersättning: förekomst av skattepliktiga ersättningar från socialförsäkringen - förekommer (ref.); förekommer inte (1). Innefattar ersättningar som föräldra- och sjukpenning, men inte sådana ersättningar som är ej skattepliktiga (exempelvis barnoch bostadsbidrag).

- Löneinkomster: förekommer (ref.); förekommer inte (1). Innefattar skattepliktiga inkomster från lönearbete och a-kassa.

- Långvarig 2007: nej (ref.); ja (1). Som långvariga räknas klienter som uppburit socialbidrag $\geq 10$ månader under 2007.
- Somatisk ohälsa: nej(ref); ja(1). Bygger på ansvarig handläggares bedömning av problemets förekomst.

- Psykisk ohälsa: nej (ref); ja (1). Bygger på ansvarig handläggares bedömning av problemets förekomst.

- Psykosociala problem: $n e j(\mathrm{ref}) ; j a(1)$. Bygger på ansvarig handläggares bedömning av förekomst av a) missbruk av alkohol/droger/spel och/eller b) övriga typer av psykosociala problem (våldsutsatt, vårdnadstvist, hemlöshet, etc.).

\section{Resultat}

I Tabell 3 redovisas de oberoende variabler som används i de kommande multiva-

\section{Tabell 3.}

Ensamstående mödrar med socialbidrag. Beskrivning av undersöknings-gruppen. Medelvärden och procent $(n=836-875)$.*

\begin{tabular}{|c|c|}
\hline Bostadsort (\%) & \\
\hline Stockholm & 39 \\
\hline Göteborg & 41 \\
\hline Malmö & 20 \\
\hline Etnicitet (svenskfödda) (\%) & 36 \\
\hline Ålder $(m)^{* * *}$ & 36,2 \\
\hline Utbildningsnivå (zgymnasium) (\%) & 31 \\
\hline Arbete $(\%)$ & 25 \\
\hline Socialförsäkringsersatta (\%) & 18 \\
\hline Löneinkomster $(\%)$ & 16 \\
\hline Långvarigt bidragstagande 2007 (\%) & 43 \\
\hline Somatisk ohälsa $(\%)$ & 27 \\
\hline Psykisk ohälsa (\%) & 29 \\
\hline Psykosociala problem (\%) & 26 \\
\hline
\end{tabular}


riata analyserna. Av tabellen framgår att 20 procent av klienterna är bosatta i Malmö, medan den resterande delen är jämnt fördelad mellan Stockholm och Göteborg. Vidare är strax under två tredjedelar av klienterna födda utanför Sverige. Medelåldern uppgår till omkring 36 år.

Framgår gör även att närmare 70 procent av undersökningsgruppen som högst har fullgjort nioårig grundskola. 75 procent av klienterna saknar arbete och andelen med skattepliktiga inkomster är ännu lägre. Drygt 40 procent av undersökningsgruppen uppbar socialbidrag långvarigt under 2007. Förekomsten av hälsorelaterade problem ligger i trakterna av vad tidigare forskning på området har redovisat. Psykosocial problematik förekommer i något lägre utsträckning än i andra bidragstagargrupper (Nybom et al., 2005; Socialstyrelsen, 2010; Stranz, 2002; Stranz \& Wiklund, 2011).

I Tabell 4 redovisas i vilken utsträckning den standardiserade socialbidragsnormen i undersökningsgruppen uppfylls. Här framgår inledningsvis att närmare hälften av klienterna har sammantagna inkomster (lön och andra skattepliktiga ersättningar, bidrag/ej skattepliktiga ersättningar samt socialbidrag) som understiger nivån på den standardiserade socialbidragsnormen.

Då den standardiserade normen inte möjliggör beaktandet av individuella variationer, kan finnas anledning att förhålla sig till en mindre strikt definition. Av tabellen framgår dock att närmare en fjärdedel av klienterna återfinns i en grupp vars inkomster understiger 90 procent av normen. Även om våra estimat vad gäller t.ex. boendekostnader föranleder försiktiga tolkningar, indikerar resultaten att socialbidraget i påfallande låg utsträckning uppfyller den standardiserade normen.

Av Figur 1 framgår att klienternas bostadsort fyller en betydande roll för om den standardiserade socialbidragsnormen uppnås. Klienter bosatta i Göteborg eller Malmö löper större risk att inte nå en full socialbidragsnorm jämfört med de i Stockholm. För Malmö är oddskvoten nära nog dubbelt så hög. Variationerna mellan städerna kan till viss del väntas bottna $\mathrm{i}$

\section{Tabell 4.}

Ensamstående mödrar med socialbidrag. Hushäll som når full standardiserad socialbidragsnorm samt andel av norm iövriga hushaill. Procent $(n=711)$.*

\begin{tabular}{lcc}
\hline & Andel & n \\
\hline Uppfylld norm & 52 & 369 \\
Andel av norm & 25 & 175 \\
$\mathbf{9 0 - 9 9 \%}$ & 14 & 103 \\
$\mathbf{7 5 - 8 9 \%}$ & 9 & 64 \\
$\mathbf{5 7 4 \%}$ & & \\
\hline * $n$ är nedjusterat till följd av tidigare nämnda internbortfall på enskilda inkomstuppgifter. Ytterligare elva fall har exklu- \\
derats ur beräkningarna då klientens sammantagna inkomst betraktas som outlier (>27 000 kronor).
\end{tabular}

Hugo Stranz \& Stefan Wiklund: Oskälig levnadsnivå? En studie av inkomstnivåer... 
det faktum att bedömningen av socialbidrag bygger på lokalt utformade regelverk, vilka i sin tur ska tolkas på handläggarnivå (Stranz, 2007). Det innebär att definitionen av en skälig levnadsnivå kan skilja sig åt både mellan och inom organisationer. Möjligen kan utformningen av, och karaktären på, de lokala regelverken i landets storstäder dessutom avvika från liknande processer i andra kommuner. Här ska utöver de lokala förhållanden som gäller för staden i dess helhet, även mer stadsdelsspecifika förhållanden beaktas. Då incitamenten för bedömningsvariationer ökar för varje regeluppsättning som tillförs arbetet (Evans \& Harris, 2004), kan utrymmet för lokala skillnader tänkas vara särskilt omfattande i stadsdelsindelade områden.
Även om vi saknar empiriskt underlag för att knyta variationerna till organisatoriska faktorer i form av varierande arbetssätt, tillämpning av olika arbetsmetoder, skillnader i socialarbetarnas kollektiva syn på bidragstagare, etc., kan inte uteslutas att sådana aspekter kan påverka utfallet mellan städerna. Denna typ av faktorer är av betydelse för socialarbetares löpande bedömningsarbete (Hydén, 1996; Kullberg, 2005; Stranz, 2007; Wallander \& Blomqvist, 2008; jämför även Brunsson \& Jacobsson, 1998; May \& Winter, 2009), vilket innebär att de också kan fylla en funktion för variationer i uppfattningarna om vad som är att beteckna som en skälig levnadsnivå.

I Tabell 5 redovisas de tidigare presenterade klientegenskapernas och klientför-

\section{Figur I.}

Boendeortens betydelse för bristande normuppfyllelse. Logistisk regressionsanalys, oddskvoter och p-värden $\left(^{*}=p<0,05^{* *}=p<0,01^{* * *}=p<0,001\right)$ iparentes $(n=668)$.*

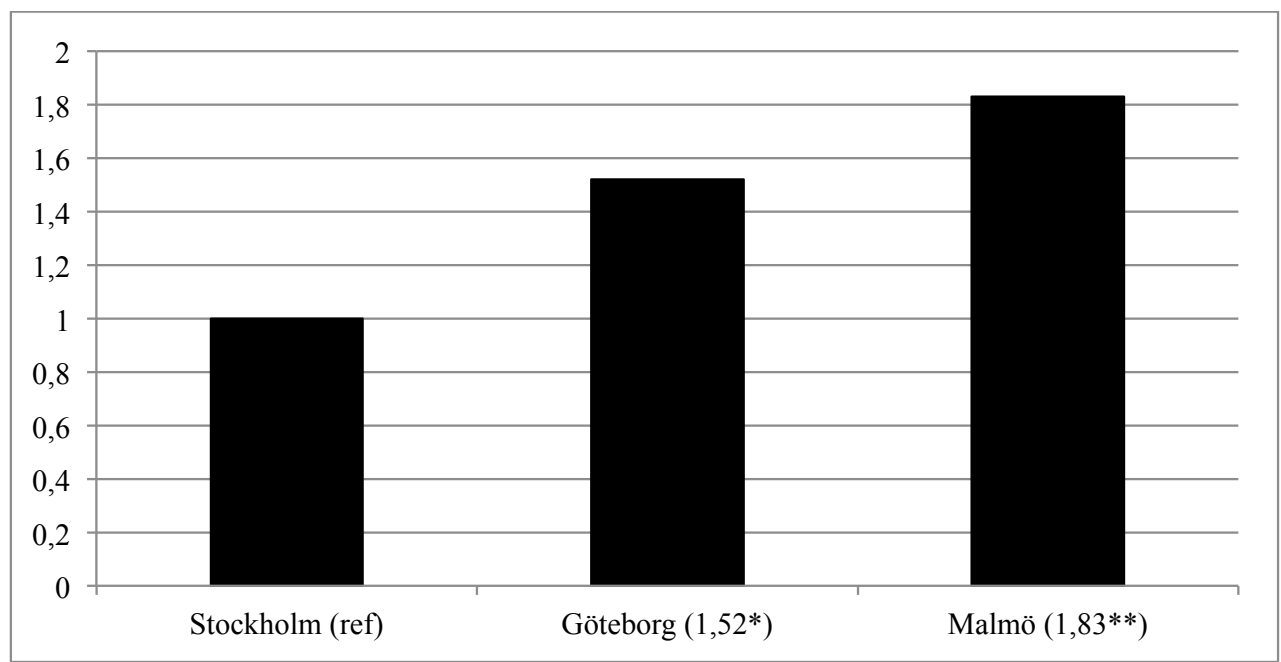

* I analysen konstanthålls faktorerna etnicitet, ålder, utbildningsnivå, arbetslöshet, förekomst av socialförsäkringsersättning, förekomst av löneinkomster, långvarigt bidragstagande 2007, förekomst av somatisk ohälsa, psykisk ohälsa samt psykosocial problematik, vilka samtliga behandlas som oberoende variabler i Tabell 5. 
hållandenas betydelse för om klienterna når upp till den standardiserade socialbidragsnormen. Av de bivariata analyserna framgår att flera av de presenterade variablerna saknar betydelse. Mot bakgrund av i första hand resultat från tidigare forskning, bibehålls även de variabler som inte faller ut som signifikanta i den multivariata analysen.

Av den multivariata analysen framgår att flera av de samband som etablerades på bivariat nivå försvinner med kontroll för övriga faktorer. Bland de faktorer som knyter an till mer grundläggande egenskaper kvarstår emellertid betydelsen av etnicitet; oddskvoten för att utrikes födda klienter inte ska nå full socialbidragsnorm är signifikant högre jämfört med svenskfödda. Vi har sedan tidigare, bl. a. vad gäller varaktighet i bidragstagandet och disponibla inkomster, visat på liknande tendenser till särskild utsatthet bland utrikes födda klienter. Mycket tyder därtill på att socialtjänstens mer aktiva klientarbete, t.ex. via olika typer av arbetsmarknadsinsatser, är mindre vanliga i förhållande till invandrare (Stranz \& Wiklund, 2011, 2012; jämför även Mood, 2011).

En tänkbar förklaring till att utrikes födda klienter löper större risk än svenskfödda att inte nå en full norm har att göra med den individuella diskretionen på handläggarnivå (jämför Lipsky, 1980; Stranz, 2007). Möjligen är utrikes födda klienter generellt sett i större behov av individuellt avpassad information än svenskfödda. Med hänsyn till organisationernas krav på masshantering av ärenden (Lipsky, 1980), kan sådana behov vara svåra att möta. Därmed kan det även finnas en ökad risk att den enskilda klientens särskilda behov - och förutsättningar för normuppfyllelse - ges mindre uppmärksamhet.

Av analysen framkommer även att sam-

\section{Tabell 5.}

Faktorer av betydelse för bristande normuppfyllelse. Logistisk regressionsanalys, oddskvoter ( $n=668)$.

\begin{tabular}{|c|c|c|c|c|c|}
\hline & \multicolumn{2}{|c|}{ Bivariat } & \multicolumn{3}{|c|}{ Multivariat } \\
\hline & OR & $P$ & OR & $p$ & $\mathrm{Cl}(95 \%)$ \\
\hline Etnicitet (ref.svenskfödd) & 1,52 & ,009 & 1,43 & 039 & $|, 02-2,0|$ \\
\hline Ålder & 0,98 &, 016 & 0,98 & 052 & $0,97-1,00$ \\
\hline Utbildning (ref. zgymnasium) & 1,18 & ,299 & $|| \mid$, &, 545 & $0,79-1,56$ \\
\hline Arbetslöshet (ref.nejli arbete) & 1,12 &, 519 & 1,03 & ,905 & $0,67-1,57$ \\
\hline Socialförsäkringsersättning (ref.förekommer) & ।,79 & ,003 & 1,83 & ,004 & $1,21-2,78$ \\
\hline Löneinkomster (ref.förekommer) & 1,53 & ,036 & 1,57 & ,066 & $0,97-2,53$ \\
\hline Långvarig 2007 (ref.nej) & 1,05 & ,767 & 0,92 & ,646 & $0,66-1,30$ \\
\hline Somatisk ohälsa (ref.nej) & 0,66 & .015 & 0,73 &, 103 & $0,50-1,07$ \\
\hline Psykisk ohälsa (ref.nej) & 0,73 &, 065 & 0,95 &, 818 & $0,64-1,42$ \\
\hline Psykosociala problem (ref.nej) & 0,81 &, 207 & 0,89 &, 549 & $0,60-1,31$ \\
\hline Pseudo $\mathbf{R}^{2}$ & & & & &, 060 \\
\hline
\end{tabular}

Hugo Stranz \& Stefan Wiklund: Oskälig levnadsnivå? En studie av inkomstnivåer... 
bandet mellan avsaknad av löneinkomster och att den standardiserade normnivån inte uppfylls, utgår med kontroll för övriga variabler. Detsamma gäller för det inflytande av somatisk ohälsa som framkom på bivariat nivå. Inte heller någon av de övriga hälsorelaterade variablerna är av betydelse för klienternas möjlighet att nå full socialbidragsnorm. Oddskvoten för klienter som saknar ersättning från socialförsäkringen förändras dock inte nämnvärt. Sammantaget sammanfaller dessa resultat väl med de diskussioner som förs i tidigare forskning på området. För det första har socialbidragstagarpopulationens karaktär förändrats över tid - traditionell individuell problematik är av mindre central betydelse för behovet av socialbidrag idag än tidigare (Halleröd, 2003; Mood, 2011; Stranz \& Wiklund, 2012). Möjligen kan detta få konsekvenser även för fastställandet av en skälig levnadsnivå, $\mathrm{i}$ den meningen att handläggare tillmäter renodlade klientegenskaper och mer strukturellt orienterade förhållanden allt större vikt i bedömningsarbetet (jämför t.ex. Kullberg, 2005, 2006; Stranz, 2007). För det andra visar resultatet att avsaknad av ersättning från socialförsäkringen har kopplingar till bristande normuppfyllelse. Hur sambandet i realiteten tar sig uttryck är svårt att spekulera i, men tydligt är att socialbidragets funktion som det yttersta ekonomiska skyddsnätet kan ifrågasättas i förhållande till ensamstående mödrar.

\section{Sammanfattande diskussion}

I denna artikel har vi beskrivit och analyserat i vilken utsträckning socialbidragsta- gande ensamstående mödrar i Stockholm, Göteborg och Malmö uppnår en standardiserad socialbidragsnorm. Vi har även studerat faktorer som är av betydelse för att normen inte uppnås. Av resultaten framgår - för det första - att närmare hälften av klientgruppen inte når upp till en ersättningsnivå som motsvarar full socialbidragsnorm. Beräkningarna är visserligen förenade med vissa begränsningar, men även då vi förhåller oss till en mindre strikt definition, kvarstår höga andelar som inte når full socialbidragsnorm. Närmare en fjärdedel av klienterna återfinns på en nivå som understiger 90 procent av den standardiserade normen. Ungefär 40 procent av denna undergrupp ligger i sin tur på en nivå som motsvarar mindre än 75 procent av den standardiserade normen.

I de analyser som behandlar olika faktorers betydelse för om klienterna når upp till den standardiserade socialbidragsnormen framgår - för det andra - att enbart förhållanden som är av grundläggande eller primärt strukturell karaktär kan tillmätas någon direkt vikt. Det gäller framför allt ersättning från socialförsäkringen, i den meningen att risken för att inte nå full socialbidragsnorm är högre bland klienter som saknar sådana inkomster. Individuella klientförhållanden i form av ohälsa och psykosocial problematik saknar helt betydelse för om den standardiserade normen nås.

Av särskild betydelse för bristande normuppfyllelse är klienternas bostadsort; jämfört med klienter i Stockholm, löper de som är bosatta i Malmö en dubbelt så stor risk att inte nå upp till den standardiserade normen. Även oddskvoten för Göteborg faller ut som signifikant. Skillna- 
derna mellan städerna är inte ett resultat av exempelvis varierande demografisk profil - i analysen kontrolleras för inflytande av faktorer som ålder och etnicitet. Att vara utrikes född innebär i sin tur att möjligheterna att nå den standardiserade normen reduceras markant. Med tanke på den särskilda utsatthet ensamstående mödrar av utländsk härkomst befinner sig i (Stranz \& Wiklund, 2011, 2012), är resultaten inte särskilt överraskande. Det gör dock inte det faktum att även graden av normuppfyllelse är lägre bland utrikes födda klienter mindre alarmerande.

Resultaten visar - för det tredje - att variationerna till största delen är oförklarade. Det faktum att i första hand strukturellt relaterade faktorer, däribland klienternas bostadsort, är av betydelse för att förstå skillnaderna i bristande normuppfyllelse, föranleder vissa reflektioner kring socialtjänstens praktiska arbete med målgruppen. Härvidlag saknar vi visserligen empiriskt stöd, men det är sedan tidigare känt att exempelvis karaktär på lokala regelverk och specialiseringsgrad bland handläggare är av betydelse för bedömningsvariationer (se t.ex. Hydén et al., 1995; Stranz, 2007; Terum, 2002). Därutöver finns ytterligare och mer svårfångade organisatoriska förhållanden som kan vara av vikt vid bedömningen av en skälig levnadsnivå. Det gäller t.ex. institutionell tröghet $i$ form av att lokala ideologier och synsätt ofta är svårföränderliga (Trydegård, 2000; Wiklund, 2006). Med andra ord är det tänkbart att socialbidragshandläggning i viss utsträckning styrs av värderingar som "sitter i väggarna" på det lokala socialkontoret.

Klarlagt i artikeln är också att flera av de begrepp som ska fungera både vägledande och styrande i socialtjänstens arbete med socialbidrag saknar ett konkret innehåll i relation till ensamstående mödrar. Det gäller inte bara tillförsäkrandet av en skälig levnadsnivå - såsom vi definierat begreppet - som tycks vara giltigt bara i viss utsträckning och i relation till vissa undergrupper bland de ensamstående mödrarna; med hänsyn till variationerna mellan landets tre storstäder kan även den generella principen om att socialbidragets nivå ska vara jämförbar med vad en låginkomst tagare på orten kan kosta på sig, betraktas som uppenbart otydlig.

Våra resultat föranleder också att barnperspektivets genomslag i bedömningen av socialbidrag till ensamstående mödrar kan ifrågasättas. Som framgått lever runt fyra procent av landets barn i denna hushållstyp (Socialstyrelsen, 2011) och en betydande del av dem löper alltså en risk att inte tillförsäkras en skälig levnadsnivå. Bostadsortens förklaringsvärde i relation till uppfyllelsen av vår standardiserade norm sammanfaller även med Rädda Barnens analyser av barns ekonomiska utsatthet - Malmö är den kommun i landet som uppvisar den högsta andelen barn som lever i hushåll som enligt Rädda Barnens definition är att beteckna som fattiga (Salonen, 2012). Då tidigare forskning dels pekar mot att socialbidragstagande i vissa avseenden kan ärvas (Stenberg, 2000), dels att barn till ensamstående mödrar tenderar att vara överrepresenterade i den sociala barnavården (Lundström \& Sallnäs, 2003), finns i kommande studier goda skäl att ägna situationen för barnen till ensamstående mödrar med socialbidrag särskild uppmärksamhet.

Hugo Stranz \& Stefan Wiklund: Oskälig levnadsnivå? En studie av inkomstnivåer... 


\section{Referenser}

Bergmark, Å. \& Bäckman, O. (2004). Stuck with Welfare? Long-term Social Assistance Recipiency in Sweden. European Sociological Review, vol. 20(5), ss. 425-443.

Bergmark, Å. \& Bäckman, O. (2007). Socialbidragstagandets dynamik - varaktighet och utträden från socialbidragstagande under 2000-talet. Socialvetenskaplig tidskrift, vol. 14 (2-3), ss. 134-152.

Borgeraas, E. \& Dahl, E. (2010). Low income and 'poverty lines' in Norway: a comparison of three concepts. International Journal of Social Welfare, vol. 19(1), ss. 73-83.

Brunsson, N. \& Jacobsson, B. (1998). Standardisering. Stockholm: Nerenius \& Santréus.

Dahl, E. \& Lorentzen, T. (2003). Dynamics of social assistance: the Norwegian experience in comparative perspective. International Journal of Social Welfare, vol. 12(4), ss. 55-65.

Dellgran, P. \& Höjer, S. (2003). Unbalanced Professionalisation. On Status and Stratification in Swedish Social Work. Social Work in Europe, vol. 10 (2), ss. 37-48.

Evans, T. \& Harris, J. (2004). Street-Level Bureaucracy, Social Work and the (Exaggerated) Death of Discretion. British Journal of Social Work, vol. 6 (34), ss. 871-895.

Fritzell, J., Gähler, M. \& Nermo, M. (2007). Vad hände med 1990-talets stora förlorargrupper? Välfärd och ofärd under 2000-talet. Socialvetenskaplig tidskrift, vol. 14(2-3), ss. 110-133.

Gähler, M. (2001). Bara en mor - ensamstående mödrars ekonomiska levnadsvillkor i 1990talets Sverige. I Bergmark, Å. (red.), Ofärd i välfärden (SOU 2001:54). Stockholm: Fritzes, ss. 15-100.

Halleröd, B. (2003). Varför får folk socialbidrag? Analys av socialbidragstagandets bestämningsfaktorer. Socialvetenskaplig tidskrift, vol. 10 (2-3), ss. 238-266.

Hammarstedt, M. (2009). Assimilation and participation in social assistance among immigrants. International Journal of Social Welfare, vol. 18 (1), ss. 85-94.
Hasenfeld, Y. (1983). Human Service Organizations. Englewood Cliffs, N. J.: Prentice-Hall.

Hjort, T. (2010). Skälig levnadsnivå eller miniminivå - om välfärdsstatens syn på socialbidragstagares konsumtion. Socionomens forskningssupplement, 27, ss. 68-75.

Hydén, L-C., Kyhle Westermark, P. \& Stenberg, S-Å. (1995). Att besluta om socialbidrag. En studie i 11 kommuner (CUS-skrift 1995:1). Stockholm: Socialstyrelsen, CUS.

Hydén, L-C. (1996). Att besluta om socialbidrag. Förändringar av beslut och attityder till socialbidrag 1990-1994. Socialvetenskaplig tidskrift, vol. 3 (3), ss. 180-194.

Johansson, H. (2001). I det sociala medborgarskapets skugga. Rätten till socialbidrag under 1980- och 1990-talen. Lund: Arkiv.

Kjellberg, A. (2010). Växande avgiftsskillnader $i$ a-kassan - ökad social polarisering. Lund: Lunds universitet, Sociologiska institutionen.

Konsumentverket (2007). Skäliga levnadskostnader. Beräkningar av Konsumentverket (Rapport 2007:11). Karlstad: Konsumentverket.

Kullberg, C. (2005). Differences in the Seriousness of Problems and Deservingness of Help: Swedish Social Workers' Assessments of Single Mothers and Fathers. British Journal of Social Work, vol. 35 (3), ss. 373-386.

Kullberg, C. (2006). Paid work, education and competence. Social workers' interviews with male and female clients applying for income support. European Journal of Social Work, vol. 9(3), ss. 339-355.

Lipsky, M. (1980). Street-Level Bureaucracy. Dilemmas of the Individual in Public Services. New York: Russell Sage.

Lundström, T. \& Sallnäs, M. (2003). Klass, kön och etnicitet i den sociala barnavården. Socialvetenskaplig tidskrift, vol. 10(2-3), ss. 193-213.

May, P.J. \& Winter, S. C. (2009). Politicians, Managers, and Street-Level Bureaucrats: Influences on Policy Implementation. Journal of Public Administration Research and Theory, vol. 19 (3), ss. 453-476. 
Mood, C. (2011). Lagging behind in good times: immigrants and the increased dependence on social assistance in Sweden. International Journal of Social Welfare, vol. 20 (1), ss. 55-65.

Nermo, M. (2004). Sida vid sida men inte på jobbet: en analys av könssegregerade arbetsmarknader. I Florin, C. \& Bergqvist, C. (red.), Framtiden i samtiden: könsrelationer i förändring $i$ Sverige och omvärlden. Stockholm: Institutet för framtidsstudier, ss. 108-139.

Nybom, J. (2011). Activation in social work with social assistance claimants in four Swedish municipalities. European Journal of Social Work, vol. 14 (3), ss. 339-361.

Nybom, J. (Red.), Puide, A., Roselius, M. \& Hjulström, F. (2005). Förutsättningar för socialbidragsarbete - en jämförelse mellan fyra kommuner. Stockholm: IMS/Socialstyrelsen.

Regeringens proposition. Prop. 1979/80:1. Om socialtjänsten.

Regeringens proposition. Prop. 1996/97:124. Ändringar i socialtjänstlagen.

Regeringens proposition. Prop. 2000/01:80. Ny socialtjänstlag m.m.

Renwick, T. J. \& Bergmann, B. R. (1993). A BudgetBased Definition of Poverty With an Application to Single-Parent Families. The Journal of Human Resources, vol. 28 (1), ss. 1-24.

Salonen, T. (2012). Barns ekonomiska utsatthet. Arsrapport 2012. Stockholm: Rädda Barnen.

Socialstyrelsen (2000). Biståndsbedömning efter socialtjänstlagens reformering 1998. 2 delstudier. Stockholm: Socialstyrelsen.

Socialstyrelsen (2006). Social rapport 2006. Stockholm: Socialstyrelsen.

Socialstyrelsen (2007). Översyn av riksnormen. Stockholm: Socialstyrelsen.

Socialstyrelsen (2010). Social rapport 2010. Stockholm: Socialstyrelsen.

Socialstyrelsen (2011). Ekonomiskt bistånd årssta tistik år 2010. Utbetalda belopp samt antal mot tagare och antal biståndshushåll. Stockholm: Socialstyrelsen.

Socialstyrelsen (2012). Kartläggning om skälig levnadsnivå. Överensstämmelse mellan SOSFS 2003:5 och kommunernas styrdokument för ekonomiskt bistånd. Stockholm: Socialstyrelsen.

Statistiska centralbyrån [SCB]/Statistiska meddelanden BO 39 SM 0801. Hyror i bostadslägenheter 2007. Stockholm: SCB.

Stenberg, S-Å. (2000). Inheritance of Welfare Recipiency: An Intergenerational Study of Social Assistance Recipiency in Postwar Sweden. Journal of Marriage and the Family, vol. 62 (1), ss. 228-239.

Stranz, H. (2002). Långvarigt socialbidragstagande - en studie i två kommuner. Stockholm: Svenska Kommunförbundet.

Stranz, H. (2007). Utrymme för variation - om prövning av socialbidrag (Rapport i Socialt arbete, 119). Stockholm: Stockholms universitet, Institutionen för socialt arbete.

Stranz, H. \& Wiklund, S. (2011). I välfärdssamhällets marginal - om socialbidragstagande bland ensamstående mödrar av svensk och utländsk härkomst. Socialvetenskaplig tidskrift, vol. 18 (1), ss. 42-62.

Stranz, H. \& Wiklund, S. (2012). Risk factors of long-term social assistance recipiency among lone mothers. The case of Sweden. European Journal of Social Work, DOI:10.1080/1369145 7.2012.702312.

Svensson, G. (2000). Skälig levnadsnivå och goda levnadsvillkor. Bedömning i förvaltningsdomstolar och socialnämnder. Stockholm: Norstedts.

Tabachnick, B. G. \& Fidell, L. S. (2001). Using Mul tivariate Statistics. Boston: Allyn \& Bacon.

Terum, L-I. (2002). Portvakt i velferdsstaten. Om skjønn og beslutninger $i$ sosialt arbeid. Oslo: Kommuneforlaget.

Trydegård, G.-B. (2000). Tradition, change and variation: present trends in public old-age care (SSSW, 16). Stockholm: Stockholms universitet, Institutionen för socialt arbete.

Wallander, L. \& Blomqvist, J. (2008). Modeling Ideal Treatment Recommendations: A Factorial Survey of Swedish Social Workers' Ideal Recommendations of Inpatient or Outpatient Treatment for Problem Substance Users. Journal of Social Service Research, vol. 35 (1), ss. 47-64.

Hugo Stranz \& Stefan Wiklund: Oskälig levnadsnivå? En studie av inkomstnivåer... 
Wiklund, S. (2006). Barnavårdsinsatser - en studie av kommunala skillnader. Socialvetenskaplig tidskrift, vol. 13(3), ss. 244-259.

Yazdanpanah, S. (2008). Att upprätthålla livet. Om lågavlönade ensamstående mödrars försörjning $i$ Sverige (Stockholm Studies in Economic History, no. 54.). Stockholm: Stockholms universitet, Ekonomisk-historiska institutionen.

\section{Summary}

\section{Inadequate living? \\ On benefit levels and norm fulfilment among single mothers on social assistance}

The aim of this article is twofold: (a) to describe to what extent net earnings of single mothers on social assistance meet a standardized norm; and (b) to analyse factors associated with lack of norm fulfilment within this group. The sample consists of randomly selected single mothers $(\mathrm{n}=875)$ receiving social assistance during 2007 in Stockholm, Gothenburg or Malmö. Data used in the analyses consist of net household incomes (based on information from responsible case managers regarding wage earnings, social security transfers/benefits and social assistance benefits) which are related to a constructed norm based on criteria guiding social workers' assessments in regular case work (i.e. standardized costs for rent as well as individual and household expenditures).

The main results are: (a) only about 50 per cent of the recipients' net income meet the standardized norm and about 25 per cent of the sample do not exceed 90 per cent of this norm; (b) there are substantial differences in norm fulfilment between recipients in the three cities (OR for recipients not to meet norm is 1.52 in Gothenburg and 1.83 in Malmö in comparison to Stockholm); (c) lack of social security transfers and being of non-native origin represent factors associated with the highest OR for lack of norm fulfilment; and (d) lack of norm fulfilment is mostly unexplained, suggesting that factors from the organizational level (e.g. institutional values) may be of importance. The results indicate that case workers' adherence to guiding principles for assessing benefit levels is lacking for this particular group. This, in turn, may have considerable impact on the vast number of children concerned. 